\title{
Impacts of Wire Basket Retention and Removal on Planting Time, Root-Ball Condition, and Early Growth of Acer platanoides and Gleditsia triacanthos var. inermis
}

\author{
Andrew Koeser, Richard Hauer, Jeff Edgar, and David Kleinhuizen
}

\begin{abstract}
The use of wire baskets to maintain root-ball integrity has greatly increased the efficiency of balled-and-burlapped harvesting practices. Despite the advantages offered by these products, there is notable disagreement among green industry groups and practitioners regarding the effects of wire basket retention or removal at the time of planting. For this experiment, 30 Norway maple (Acer platanoides) and 30 honeylocust (Gleditsia triacanthos var. inermis 'Skycole') shade trees were evenly planted at two sites in the midwestern U.S. after random assignment of a wire-basket removal treatment (i.e., no removal/intact, partial removal, and full removal). Planting time and initial root-ball condition were assessed at the time of installation. Short-term growth and plant stress were assessed each season as trees became established in the research plots. Results indicate that treatment impacted both planting time $(P<0.0001$; both sites $)$ and root-ball condition $(P=0.0360$ or $P=0.0049$; depending on site). In contrast, treatment had limited impact on tree caliper, twig elongation, or chlorophyll fluorescence in the first two to three years after planting.

Key Words. Acer platanoides; Burlap; Gleditsia triacanthos; honeylocust; Midwest; Minnesota; Norway maple; Planting Survival; Transplanting; Tree Stability; Wire Basket; Wisconsin.
\end{abstract}

Wire baskets were developed as a means of maintaining root-ball integrity for mechanically harvested balled-and-burlapped trees (Appleton and Floyd 2004). While these metal support systems offer many efficiencies and advantages over traditional hand-drum-lacing techniques, their use has generated notable controversy (Lumis 1990a; Appleton and Floyd 2004). Many tree-care professionals worry about potential long-term conflicts between root growth and persisting wire. Unlike natural fiber ties, steel wires have the potential to persist in the soil for years or even decades when buried (Watson and Himelick 2013). While observational research accounts have shown that tree roots can eventually engulf the wire used for basket construction (Lumis and Struger 1988; Lumis 1990b), lingering fears regarding the impact of wire baskets on longterm growth and stability are reflected in the many arboricultural texts and best management practices that advocate for at least partial basket removal
(Harris et al. 2004; Watson and Himelick 2005; Urban 2008; Lilly 2010; Watson and Himelick 2013).

In contrast with these recommendations, Appleton and Floyd (2004) noted that many nursery producers worry that the full or partial removal of wire baskets may lead to additional root-ball disruption and fine-root loss. Fine-root loss, separation from the surrounding soil, and desiccation are believed to be significant factors associated with reduced growth and survival of transplanted trees (Harris and Bassuk 1993; Koeser et al. 2009). As such, wire-basket removal is seen by some nursery growers as a significant hindrance to plant establishment. Some producers have even considered it as a justification for voiding plant material warranties (Appleton and Floyd 2004).

In a 2004 literature review on wire basket handling practices, Appleton and Floyd (2004) identified 17 primary and secondary sources that directly addressed wire-basket removal. Of the 
cited publications, only two papers (Lumis and Struger 1988; Goodwin and Lumis 1992) had been formally peer-reviewed. In the earlier of these two works, the authors offered a photographic account of 11-year old willow (Salix spp.) tree roots fully engulfing the upper portions of their original wire basket (Lumis and Struger 1988). The work was not a designed experiment; rather, it served as a first attempt to document regrowth of vascular tissues around partially girdling basket wire. To date, the only formal experimentation on this issue was a six-month greenhouse experiment where root systems of two-year-old liners were intentionally girdled at various levels with florist wire to simulate conditions faced in the landscape (Goodwin and Lumis 1992).

This research offers a controlled assessment of the impacts of wire-basket removal and retention on tree growth and survival of larger nursery stock commonly planted in urban landscapes. The findings reported in this paper address early growth and survival following transplanting. Additionally, initial root-ball condition at installation and time required for planting are compared and discussed for various levels of basket retention and removal. Surviving trees will be reassessed in the years to come to address concerns regarding long-term plant health and stability.

\section{MATERIALS AND METHODS}

\section{Locations}

Two study sites were selected within the upper midwest United States. The first planting site was established at a commercial nursery in Manitowoc, Wisconsin, U.S. (lat. $44.049877 \mathrm{~N}$, long. 87.673654 W, USDA Hardiness Zone 5b) on June 28, 2011. The second planting site was located at a commercial nursery in Forest Lake, Minnesota, U.S. (lat. 45.214867 N, long. 92.952985 W, USDA hardiness zone $4 \mathrm{~b}$ ) with the trial beginning on May 10, 2012. Planting sites were intentionally separated geographically and temporally (with planting dates staggered over two years) to capture more than one initial growing environment (site). At the Wisconsin site, trees were planted into a Keowns very fine sandy loam (U.S. Dept. Agriculture 2007). At the Minnesota site, trees were planted into a Lino variant loamy fine sand (U.S. Dept. Agriculture 2011).

\section{Plant Materials}

Two commonly-planted urban shade tree species, honeylocust [Gleditsia triacanthos L. var. inermis (L.) C. K. Schneid 'Skycole'] and Norway maple (Acer platanoides L.), were selected for comparison in this study. All plant materials were field-grown, harvested, and balled-andburlapped with standard, tapered wire baskets constructed from $2.5 \mathrm{~mm}$ wire. The burlap bags used were treated and constructed from $339 \mathrm{~g} \cdot \mathrm{m}^{-2}$ natural jute material. Honeylocust were $5.0 \mathrm{~cm}$ to $6.5 \mathrm{~cm}$ in caliper at the time of planting. Norway maple were $5.0 \mathrm{~cm}$ to $6.5 \mathrm{~cm}$ in caliper at the Wisconsin site and $7.5 \mathrm{~cm}$ to $9.0 \mathrm{~cm}$ in caliper at the Minnesota site at the time of planting. With the exception of the Norway maple at the Minnesota site, all tree root balls were secured in $74-\mathrm{cm}$ diameter wire baskets. The larger Norway maples at the Minnesota site were placed in $91-\mathrm{cm}$ diameter wire baskets. In all, 60 trees were used for this study (15 trees per species per site).

\section{Treatments}

At planting, trees were randomly assigned one of three treatments: 1 ) planted with wire and burlap fully intact (intact); 2) planted with the top third of the wire removed and burlap folded down as low in the hole as possible (partial removal); and 3 ) planted with the wire completely removed and the burlap folded down in the hole below the root ball (full removal) (Figure 1). For partial removal, trees were placed in the planting pit prior to wire removal and burlap loosening. For full removal, only the very bottom of the wire basket was cut and removed prior to placement in the planting hole. The sides of the tapered basket were left intact to support the root ball until the tree was completely situated in the bottom of the planting pit. Once in place, the remaining wire was removed and the burlap was loosened and folded down to the bottom of the hole. Twine (naturallyderived) was not cut on the intact treatment and left uncut for the first growing season.

All planting holes were machine dug with a skid steer (using a tree spade in Wisconsin and $\mathrm{u}$-blade in Minnesota) and later widened approximately $15 \mathrm{~cm}$ with a hand shovel to allow sufficient root ball access for wire-basket removal and burlap loosening as noted pre- 
viously. At both sites, trees were moved from their harvest location to the planting holes using a skid steer equipped with forks. Trees were backfilled manually with a shovel, and soil was tamped lightly to reduce air gaps. All trees were planted so their root flares were at or slightly $(2.5$ to $5.0 \mathrm{~cm}$ ) above grade. Field soil at both sites were typical of nursery soils. They were tilled with a field cultivator and were easily dug with a shovel. Trees were not staked or irrigated after planting. The ground between tree rows was periodically cultivated by nursery staff to limit weed competition.

\section{Measurements}

Planting time was measured for each tree installed to later compare the labor associated with each of the three treatments. Timing began once trees were positioned next to the planting hole and ended once the last of the fill had been shoveled back into place. Additionally, root-ball condition was rated prior to backfilling (after treatments had been administered). This rating system was set as a six-point scale with zero (0) equal to no rootball disruption and five (5) equal to complete bare-rooting (Table 1). As intact root balls were still covered, cracking was assessed by visual cues and by feel. The same two individuals conducted all assessments and came to a consensus on the final damage rating.

Baseline caliper measurements were taken $15.3 \mathrm{~cm}$ above grade at planting. At the end of each season, both tree caliper and twig elongation measurements were taken. Two caliper measurements were made per tree (north-south and east-west) and the location was marked with a wax pencil for future remeasurement. Twig elongation measurements were taken on the terminal shoots of the lowest three sun-exposed main branches. These branches were marked with zip-ties for remeasurement. Dark-adapted (30 minutes) chlorophyll fluorescence measurements (three per tree) were taken once during mid- to late-summer as a means of assessing relative stress among trees. Chlorophyll fluorescence measurements (Fv/ Fm) were taken with a portable photosynthesis system (LI-6400; LI-COR, Lincoln, Nebraska, U.S.) for the first two seasons. In the last season of measurement, Fv/Fm was measured using a dedicated chlorophyll fluorescence meter (OS30p+; Optisciences Inc., Hudson, New Hampshire, U.S.). All subsampling (i.e., instances where multiple measurements were made per tree) was averaged into a single measurement prior to final analysis. Trees were monitored for two seasons at the Minnesota site and for three seasons at the Wisconsin site.

\section{Design and Analysis}

Trees were grouped by species. Within each species grouping, the three wire-basket removal treatments were arranged in a completely randomized design ( $\mathrm{n}=5$ per site). Initial planting measurements (time required to plant and root-

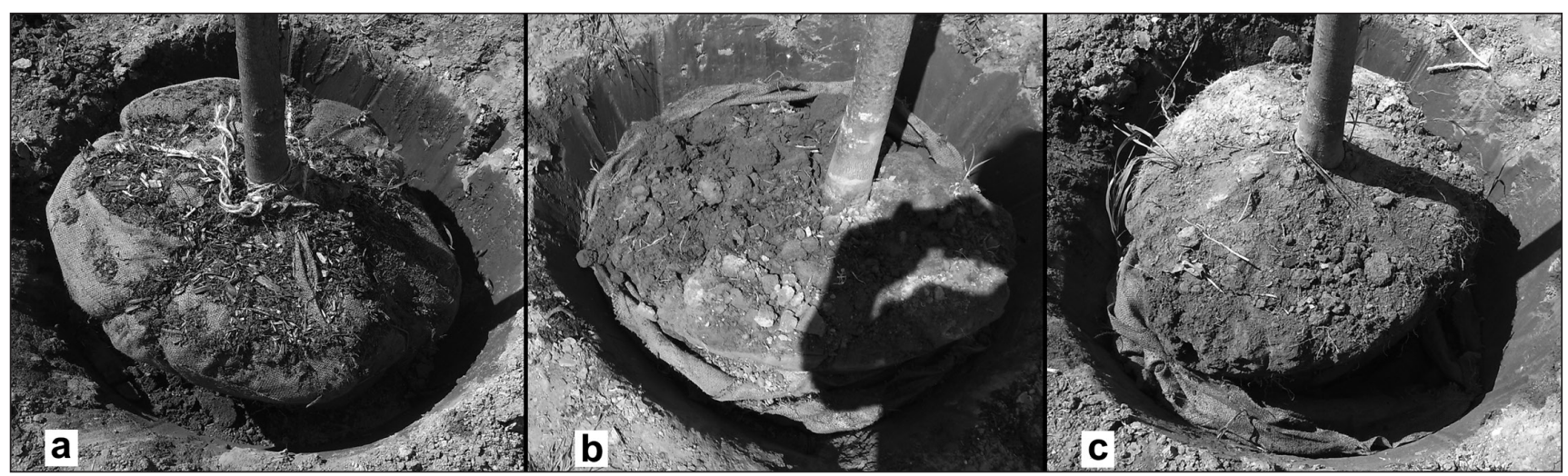

Figure 1. The three levels of wire-basket removal and retention used in this experiment. Intact trees (a) were planted with wire and burlap completely intact. Partial removal trees (b) were planted with the top half of the wire basket removed and the burlap folded down as far as possible. Full removal trees (c) were planted with the wire basket completely removed and the burlap folded down below the root ball. 
Table 1. Root-ball disruption scale. Prior to backfilling, each tree root ball was rated to assess cracking, distortion, and damage associated with planting and handling.

\begin{tabular}{cl}
\hline Rating & Description \\
\hline 0 & No disruption to root ball. \\
1 & Minor cracking. \\
2 & $\begin{array}{l}\text { Moderate cracking, but no visible root ball } \\
\text { distortion. Tree stability unaffected. }\end{array}$ \\
3 & $\begin{array}{l}\text { Moderate cracking with at least one side of the root ball } \\
\text { flattened or distorted. Noticeable difference in tree stability. }\end{array}$ \\
4 & $\begin{array}{l}\text { Severe cracking and significant distortion of overall root } \\
\text { ball shape. Stability of tree significantly affected. }\end{array}$ \\
5 & Complete bare-rooting.
\end{tabular}

ball condition) were pooled together across species and sites prior to analysis. Growth and stress responses were analyzed separately by species.

Planting-time requirement data were analyzed as Analysis of Variance (ANOVA) using the aov() function in $\mathrm{R}$ ( $\mathrm{R}$ Core Team 2013). Mean separation was conducted as a protected Fisher's Least Significant Difference test using the LSD.test() function in R. Residual plots indicated that the root-ball rating data failed to meet the assumption of normality. As such, a Kruskal-Wallis non-parametric test was used to assess the significance of the treatments. The test and resulting mean separation were conducted with the kruskal() function offered through the agricolae package in $\mathrm{R}$ (de Mendiburu 2013). Final caliper growth was analyzed using Analysis of Covariance (ANCOVA) with initial caliper, site, and treatment included as covariates. Finally, twig elongation and Fv/Fm were analyzed as repeated measures ANOVA using the lme() function in package nlme (Pinheiro et al. 2013). These analyses were also separated by site, as trees were measured for two seasons after planting in Minnesota and for three seasons after planting in Wisconsin. All decisions were made at $\alpha \leq 0.05$ significance level of type I error.

\section{RESULTS}

\section{Planting Time and Root-Ball Condition}

Overall, mean planting times for the partial and full removal treatments were approximately double that of the intact treatments at both sites $(P<0.0001$ and $P<0.001$ for Wisconsin and Minnesota, respectively, Table 2). This increased planting time by two to two and a half minutes. At both research sites, differences in planting time between the partial and full removal treatments were not significant (Table 2).

Root-ball condition rating also varied by treatment at both the Wisconsin $(P=$ $0.0360)$ and Minnesota sites $(P=0.0049)$. Similar to the pattern seen with planting time, intact trees had significantly lower damage ratings at both planting sites (Table 2 ). Intact trees had a median ranking of no damage that increased to minimal and moderate cracking levels when the burlap and wire basket were removed. Differences were not significant between the partial and full removal treatments at either site (Table 2).

\section{Caliper Growth}

For both the honeylocust and the Norway maple ANCOVA models, only initial caliper was significant $(P<0.0001$ for both species). Neither site $(P=0.1381)$ nor treatment $(P=0.8972)$ significantly impacted final caliper growth for the honeylocust. Similarly, both site $(P=0.7030)$ and treatment $(P=0.1352)$ were non-significant in the Norway maple ANCOVA models (Table 3).

\section{Twig Elongation and Chlorophyll Fluorescence}

Honeylocust twig elongation did not differ by treatment at the Wisconsin $(P=0.8018)$ or Minnesota sites $(P=0.5510)$. Similarly, treatment did not impact Norway maple twig elongation at the Minnesota site $(P=0.3320)$. The treatments were marginally significant when comparing mean twig elongation for Norway maple at the Wisconsin site $(P=0.0587)$. Fv/ Fm generally remained similar across the three treatments with one exception-Norway maple at the Minnesota site $(P=0.0109$. At this site, intact trees had higher $\mathrm{Fv} / \mathrm{Fm}$ ratios as compared to the partial $(P<0.001)$ and full $(P=0.0246)$ removal treatments (Table 3$)$. 
Table 2. Planting time and root-ball condition rating associated with full removal, partial removal, and no removal (intact) of protective wire and burlap at two different research locations of Manitowoc (Wisconsin) and Forest Lake (Minnesota). Root-ball condition was rated on a six point scale $(0=$ no disruption; $5=$ complete bare-rooting).

\begin{tabular}{llll}
\hline Site & Treatment & $\begin{array}{l}\text { Mean planting } \\
\text { time (min) }\end{array}$ & $\begin{array}{l}\text { Median } \\
\text { rating }\end{array}$ \\
\hline Manitowoc, WI & Intact & $2.45 \pm 0.35 \mathrm{a}$ & $0 \mathrm{a}$ \\
& Partial removal & $4.84 \pm 0.32 \mathrm{~b}$ & $2 \mathrm{~b}$ \\
& Full removal & $5.03 \pm 0.32 \mathrm{~b}$ & \\
& & & \\
Forest Lake, MN & Intact & $2.01 \pm 0.21 \mathrm{~b}$ & $0 \mathrm{a}$ \\
& Partial removal & $4.53 \pm 0.35 \mathrm{~b}$ & 1.5 \\
& Full removal & $4.48 \pm 0.50 \mathrm{~b}$ & $1 \mathrm{~b}$ \\
\hline
\end{tabular}

${ }^{2}$ Means separated using a protected Fisher's Least Significant Difference at $P<0.05$. Mean values with similar letters are not significantly different.

${ }^{y}$ Means separated using the kruskal() function in the agricolae package in R. Median values with dissimilar letters indicate differences significant at $P<0.05$.

Table 3. Average total caliper growth, annual twig elongation, and Fv/Fm for Norway maple (Acer platanoides) and honeylocust (Gleditsia triacanthos var. inermis 'Skycole') planted at two different research locations at Manitowoc (Wisconsin) and Forest Lake (Minnesota). At planting, each tree was assigned one of three treatments: 1) full removal of wire basket and burlap, 2) partial removal of wire basket and burlap, or 3) no removal (intact) of wire basket and burlap.

\begin{tabular}{|c|c|c|c|c|c|}
\hline Site & Species & Treatment & $\begin{array}{l}\text { Caliper } \\
\text { growth }(\mathrm{cm})\end{array}$ & $\begin{array}{l}\text { Annual twig } \\
\text { growth }(\mathrm{cm})\end{array}$ & $\mathrm{Fv} / \mathrm{Fm}^{\mathrm{z}}$ \\
\hline \multirow[t]{6}{*}{ Manitowoc, WI } & \multirow[t]{3}{*}{ Norway maple } & Intact & $1.0 \pm 0.48$ & $3.6 \pm 0.64$ & $0.67 \pm 0.04$ \\
\hline & & Partial removal & $1.2 \pm 0.11$ & $2.4 \pm 0.35$ & $0.66 \pm 0.03$ \\
\hline & & Full removal & $1.7 \pm 0.10$ & $3.5 \pm 0.35$ & $0.68 \pm 0.03$ \\
\hline & \multirow[t]{3}{*}{ Honeylocust } & Intact & $0.9 \pm 0.08$ & $15.0 \pm 1.53$ & $0.67 \pm 0.02$ \\
\hline & & Partial removal & $0.8 \pm 0.07$ & $13.3 \pm 1.79$ & $0.70 \pm 0.02$ \\
\hline & & Full removal & $0.8 \pm 0.09$ & $11.6 \pm 1.29$ & $0.70 \pm 0.02$ \\
\hline \multirow[t]{6}{*}{ Forest Lake, MN } & \multirow[t]{3}{*}{ Norway maple } & Intact & $1.1 \pm 0.18$ & $3.2 \pm 0.60$ & $0.77 \pm 0.01 \mathrm{a}$ \\
\hline & & Partial removal & $0.8 \pm 0.08$ & $2.9 \pm 0.58$ & $0.75 \pm 0.01 b$ \\
\hline & & Full removal & $1.0 \pm 0.05$ & $2.5 \pm 0.28$ & $0.75 \pm 0.01 b$ \\
\hline & \multirow[t]{3}{*}{ Honeylocust } & Intact & $0.5 \pm 0.11$ & $19.0 \pm 2.99$ & $0.78 \pm 0.01$ \\
\hline & & Partial removal & $0.6 \pm 0.07$ & $23.5 \pm 3.08$ & $0.79 \pm 0.01$ \\
\hline & & Full removal & $0.7 \pm 0.09$ & $21.8 \pm 3.15$ & $0.79 \pm 0.01$ \\
\hline
\end{tabular}

${ }^{z}$ Values with dissimilar letters indicate differences significant at $P<0.05$. Values without lettering were non-significant.

\section{DISCUSSION}

Full or partial wire basket and burlap removal increased total planting time by up to approximately two and a half minutes. According to industry averages in the U.S., the total labor required to plant a $76 \mathrm{~cm}$ wire basket (averaged from $60-\mathrm{cm}$ and $92-\mathrm{cm}$ data) is 109.0 minutes in medium soils (RSMeans 2013). This average is for a crew with two laborers and one light equipment/backhoe operator and mirrors the planting crew used in the present study. Adding the two and a half minutes to planting plus an additional minute for wire scrap cleanup would add USD $\$ 4.58$ or $3.2 \%$ to the final cost (including overhead and profit) of planting a tree (RSMeans 2013).

Wire basket and burlap removal did result in increased soil cracking and root ball distortion (Table 2). This was a concern noted by Appleton and Floyd in their review of the issue (2004). Despite this, twig elongation and caliper appeared largely unaffected by the three treatments. Similarly, with the exception of one planting of Norway maple (Wisconsin), researchers were largely unable to detect differences in plant stress (Fv/Fm), which suggests this initial disturbance linked to the treatments had minimal impact on short-term plant performance for species used in this study. Overall, average $\mathrm{Fv} / \mathrm{Fm}$ values were below the 0.78 to 0.85 range associated with healthy, non-stressed shade trees (Percival 2005), indicating all trees were stressed after transplanting regardless of treatment.

Beyond the wire itself, the retention of burlap and rope wrapping materials at planting has been a point of contention among professionals. Some believe natural burlap materials will degrade quickly in the soil, though there is some evidence that treated burlap can persist for several years after planting (Kuhns 1997; Watson and Himelick 2013). Research has shown that roots will penetrate intact burlap after transplanting; however, multiple layers of wrapping materials may limit root growth into the surrounding soil during the initial months following installation (Kuhns 1997). As these roots expand, many believe 
they may be girdled by persisting burlap (Watson and Himelick 2013). When the long-term stage of this study is completed and trees are evaluated for differences in whole-tree stability, the root systems will be excavated and inspected for signs of past girdling.

The removal of ropes to prevent stem girdling has long been recommended (Gouin 1983). In the current study, the rope was left to prevent root ball breakage from wind during the first year. Despite being constructed of natural material, the ropes at both sites were still very much intact and removed before the second growing season.

While researchers failed to note significant differences in growth rates among the three treatments, dramatic differences were witnessed in tree stability for the Norway maple three weeks after planting at the Minnesota site. A late spring windstorm toppled two of the partial and three of the full removal treatments. The remaining trees for these two treatments had visible leans. All trees were straightened and the soil was re-tamped around each. With frequent rains in the area, growing conditions at the site remained favorable after the storm, and the trees survived with no noticeable impact to growth and health.

This experience highlights the potential need for tree staking or guying materials for the two levels of wire-basket removal and is one of the arguments used by those advocating that wire and burlap be left intact (Appleton and Floyd 2004; Marshall undated). If leaving the wire basket intact is truly sufficient to prevent newly planted trees from toppling in winds, consumers would be spared a 2013 industry average of $\$ 41.50$ for staking costs in areas where wind is a concern (RSMeans 2013).

Interestingly, site did not significantly impact final caliper measurements, despite the difference in the number of seasons in the ground. The study authors believe this reflects the difference in each site's first growing season. When the Wisconsin trees were planted in 2011, the area was experiencing notably dry conditions. In contrast, when the Minnesota trees were planted in 2012, they experienced moist soil conditions characterized by frequent rain events.

This research serves as yet another indication that wire baskets do not pose significant stress to newly transplanted trees (for the species and environmental condition tested). The authors acknowledge that while this is not in contrast with past research (Lumis and Struger 1988; Goodwin and Lumis
1992), it does go counter to some of the personal experiences and accounts offered by professional arborists. It seems plausible that in some cases of transplant failure, minimally-degraded wire baskets and natural burlap materials were blamed for the death of the tree when in fact their presence was merely an indication of poor planting sites. The decay organisms that ultimately break down burlap coverings are influenced by compaction, excess/limiting soil moisture, $\mathrm{pH}$, and other soil factors that also influence tree survival. Oxidation is similarly linked to water and air availability and, noting this, researchers have used corrosion levels on steel rods as a means of gauging long-term underground growing conditions (Hodge 1994).

In less than ideal soil conditions, wire from baskets can persist for years with minimal loss of strength (Lumis 1990a; Lumis 1990b). As such, at many urban planting sites, roots may partially girdle as they grow into the remaining wire. While past observation has shown trees can recover from this potential stress, no controlled experiments have compared the growth of these trees to similar specimens not hindered by wire. Similarly, the impact of wire growth on tree stability is unknown. This population of trees will remain in the research plots for future testing in an attempt to address these questions.

\section{SUMMARY}

While this study does not end the debate regarding the removal of wire baskets and burlap after planting, the findings do offer further considerations for the best management practices of tree planting. Similarly, this work offers an estimate of planting time differences for various levels of wire-basket removal, which can be incorporated into bid proposals. Staking of trees following the removal of a wire basket is recommended as a precaution in areas where toppling from wind loading is a concern. Removal of packing materials did cause minor to moderate cracking of the root ball. However, this did not translate into reduced growth or greater stress.

Acknowledgments. This study was supported by the Tree Research and Education Endowment Fund (TREE Fund) and the Wisconsin Arborist Association, with in-kind donations from Silver Creek Nurseries, Inc., and Hardwood Creek Nurseries, Inc.

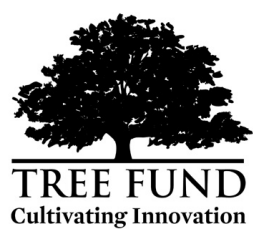




\section{LITERATURE CITED}

Appleton, B., and S. Floyd. 2004. Wire baskets: Current products and their handling at planting. Journal of Arboriculture 30(4):261-265.

de Mendiburu, F. 2013. Agricolae: Statistical Procedures for Agricultural Research. R package version 1.1-4. Accessed 02/01/2014. $<$ http://CRAN.R-project.org/package=agricolae $>$

Goodwin, C., and G. Lumis. 1992. Embedded wire in tree roots: Implications for tree growth and root function. Journal of Arboriculture 18(3):115-123.

Gouin, F.R. 1983. Girdling by roots and ropes. Journal of Environmental Horticulture 1(2):48-50.

Harris, J.R. and N.L. Bassuk. 1993. Tree planting fundamentals. Journal of Arboriculture 19(2):64-70.

Harris, R.W., J.R. Clark, and N.P. Matheny. 2004. Arboriculture: Integrated Management of Landscape Trees, Shrubs, and Vines, fourth edition. Prentice Hall, New York City, New York, U.S. 578 pp.

Hodge, S.J. 1994. Using steel rods for the non-destructive assessment of aeration in urban soils. pp. 201-206. In: G.W. Watson and D. Neely (Eds.). The Landscape Belowground-Proceedings of an International Workshop on Tree Root Development in Urban Soils. International Society of Arboriculture, Champaign, Illinois, U.S.

Koeser, A.K., J.R. Stewart, G.A. Bollero, D.G. Bullock, and D.K. Struve. 2009. Impacts of handling and transport on the growth and survival of balled-and-brulapped trees. HortScience 44:(1):53-58

Kuhns, M. 1997. Penetration of treated and untreated burlap by roots of balled and burlapped Norway maple. Journal of Arboriculture 23(1):1-7.

Lilly, S.J. 2010. Arborists' Certification Study Guide. International Society of Arboriculture, Champaign, Illinois, U.S. 352 pp.

Lumis G.P., and S.A. Struger. 1988 Root tissue development around wire-basket transplant containers. HortScience 23(2):401.

Lumis, G.P. 1990a. Wire baskets: A further look. American Nurseryman 172(4):128-131.

Lumis, G.P. 1990b. Wire baskets for moving trees: A researcher's look at trees, roots, and wire in the landscape. Landscape Trades 12(10):8-16.

Marshall, M. Undated. Wire Baskets: Why leave them intact? Accessed 06/26/2014. <www.marshalltrees.com/articles. asp? $\mathrm{p}=2 \& \mathrm{id}=152 \& \mathrm{cid}=0>$

Percival, G.C. 2005. The use of chlorophyll fluorescence to identify chemical and environmental stress in leaf tissue of three oak (Quercus) species. Journal of Arboriculture. 31(5):215-227.
Pinheiro, J., D. Bates, S. DebRoy, D. Sarkar and the R Development Core Team. 2013. nlme: Linear and Nonlinear Mixed Effects Models. R package version 3.1-109. Accessed 02/01/2014 $<$ http://CRAN.R-project.org/package $=$ nlme $>$

R Core Team. 2013. R: A language and environment for statistical computing. R Foundation for Statistical Computing, Vienna, Austria. Accessed 02/01/2014. <www.R-project.org>

RSMeans. 2013. RSMeans Site Work \& Landscape Cost Data 2014. R. Fortier (Ed.). RSMeans, Norwell, Massachusetts, U.S. 915 pp.

Urban, J. 2008. Up by Roots. International Society of Arboriculture, Champaign, Illinois, U.S. 479 pp.

Watson G.W., and E.B. Himelick. 2013. The Practical Science of Planting Trees. International Society of Arboriculture, Champaign, Illinois, U.S. 250 pp.

Watson, G.W., and E.B. Himelick. 2005. Best Management Practices: Tree Planting. International Society of Arboriculture, Champaign, Illinois, U.S. 41 pp.

Andrew Koeser (corresponding author)

Assistant Professor

Department of Environmental Horticulture

CLCE, IFAS, University of Florida

Gulf Coast Research and Education Center

14625 County Road 672

Wimauma, Florida 33598, U.S.

akoeser@ufl.edu

Richard Hauer

Professor

College of Natural Resources

University of Wisconsin-Stevens Point

800 Reserve Street

Stevens Point, Wisconsin 54481, U.S.

Jeff Edgar

Owner

Silver Creek Nurseries, Inc.

P.O. Box 1988

Manitowoc, Wisconsin 54421-1988, U.S.

Dave Kleinhuizen

President

Hardwood Creek Nursery, Inc.

18431 Henna Avenue North

Forest Lake, Minnesota 55025-3610, U.S. 
Zusammenfassung. Die Verwendung von Drahtkörben, um Wurzelballen zusammen zu halten, hat die Effizienz von ballierten Erntepraktiken enorm vergrößert. Trotz der angebotenen Vorteile dieser Produkte, gibt es eine merkbare Unstimmigkeit unter der Gruppen der Grünen Industrie und den Praktikern bezüglich der Effekte der Entfernung der Drahtkörbe während der Pflanzung oder der Beibehaltung. Für dieses Experiment wurden 30 Spitzahorne und 30 Gleditschien gleichmäßig an zwei Standorten im Mittleren Westen gepflanzt mit einer zufälligen Beauftragung einer Drahtkorbbeseitigung (z.B. keine Entfernung/Intakt, partielle und vollständige Entfernung). Die Pflanzzeit und initiale Wurzelballenkondition wurden währen der Zeit der Installation untersucht. Kurzfristiges Wachstum und Pflanzstress wurden in jeder Saison, nachdem die Bäume am Standort etabliert waren, untersucht. Die Ergebnisse zeigen, dass die Behandlung die Pflanzzeit $(P<0.0001$; beide Standorte) und die Wurzelballkondition beeinflusst $(P=$ 0.0360 or $P=0.0049$; abhängig vom Standort). Im Gegensatz dazu hatte die Behandlung einen begrenzenden Einfluss auf Baumumfang, Zweigverlängerung oder Chlorophyll-Fluoreszenz in den ersten zwei oder drei Jahren nach der Pflanzung.

Resumen. El uso de cestas de alambre para mantener la integridad de la bola de la raíz ha incrementado en gran medida la eficiencia de las prácticas de cosecha de árboles en arpillera. A pesar de las ventajas que ofrecen estos productos, hay un notable desacuerdo entre los grupos de la industria verde y profesionales sobre los efectos de la retención de la cesta de alambre o su remoción en el momento de la plantación. Para este experimento, 30 maples noruegos (Acer platanoides) y 30 acacias (Gleditsia triacanthos var. inermis 'Skycole') se plantaron de manera uniforme en dos sitios en el medio-oeste de los Estados Unidos después de la asignación aleatoria de un tratamiento con la canasta de alambre (extracción intacta/no remoción, remoción parcial y remoción completa). Inicialmente se evaluó la época de plantación y la condición inicial del cepellón. En cada temporada se evaluó el crecimiento a corto plazo y el estrés de la planta en cada temporada, a medida que los árboles se establecieron en las parcelas de investigación. Los resultados indican que los tratamientos impactaron tanto la época de plantación $(P<0,0001$; ambos sitios) como la condición de la bola de la raíz $(P=0.0360 P=0.0049$; dependiendo del sitio). En contraste, el tratamiento tuvo un impacto limitado en el calibre del árbol y en la elongación de la rama o fluorescencia de la clorofila en los primeros dos o tres años después de la plantación. 